Original Article

\title{
ADULTICIDAL ACTIVITY OF BOTANICAL OILS BY IMPREGNATED PAPER ASSAY AGAINST CULEX QUINQUEFASCIATUS SAY
}

\author{
M. RAMAR ${ }^{1,3}$, S. IGNACIMUTHU ${ }^{1}$, P. MANONMANI ${ }^{2}$, K. MURUGAN³ \\ ${ }^{1}$ Entomology Research Institute, Loyola College, Chennai-34, Tamil Nadu, India, 2Department of Biotechnology, PRIST University, Vallam, \\ Thanjavur, ${ }^{3}$ Division of Entomology, Department of Zoology, School of Life Sciences, Bharathiar, University, Coimbatore, Tamil Nadu \\ 641046, India \\ Email: ramareri@gmail.com
}

Received: 19 Oct 2016 Revised and Accepted: 31 Mar 2017

\section{ABSTRACT}

Objective: The present study was undertaken with the aim of finding out the efficacy of essential oils (EOs) as anti-mosquito agents for commercial purposes. Plant source insecticides as an alternative to chemical insecticide, this study were evaluated to assess the knock-down and adulticidal prospective of the essential oils against Culex quinquefasciatus. The plant essential oil is largely cultivated throughout India and in all Tropical countries.

Methods: The selected botanical essential oils were procured from commercial producers of plant essential oils and aromatic substances were used in this study. Knock-down and Adulticidal bioassay was performed according to WHO protocol. A single dose of the essential oils was used in the preliminary screening. 20 adult mosquitoes (3-5 d old glucose fed mosquitoes) were exposed on treated paper for one hour and knocked down and live mosquitoes were counted at 5 minute intervals.

Results: Among the twenty three oils tested, 100\% knock-down and adult mortality was recorded at $10 \% / \mathrm{cm}^{2}$ dose of calamus, camphor, cinnamon, citronella, clove, eucalyptus, lemongrass, pine, thyme and tulsi oils respectively. At $10 \%$ concentration, clove oil (KT $\mathrm{K}_{50}=1.8$ and $\mathrm{KT}_{90}=2.03$ min) was found to be the most potential treatment. After 15 min exposure period clove oil registered the lowest knock-down dose which was calculated as $\left(\mathrm{KD}_{50}=1.8 \% / \mathrm{cm}^{2}\right.$ and $\left.\mathrm{KD}_{90}=11.2 \% / \mathrm{cm}^{2}\right)$. The lower and upper $95 \%$ confidence limits for clove oil were calculated as 0.2 and 4.2 min respectively.

Conclusion: From the results it can be concluded that the adult of the Cx. quinquefasciatus were susceptible to the essential oils. Such findings would be useful in promoting research aiming at the development of new agent for mosquito control on basis of chemical compounds from indigenous plant sources as an alternative to chemicals.

Keywords: Essential oils, Screening, Filaria Mosquito, Culex quinquefasciatus, Knock-down-Adulticidal

(C) 2017 The Authors. Published by Innovare Academic Sciences Pvt Ltd. This is an open access article under the CC BY license (http://creativecommons.org/licenses/by/4.0/) DOI: http://dx.doi.org/10.22159/ijpps.2017v9i5.15764

\section{INTRODUCTION}

Mosquito diseases, such as malaria, Japanese encephalitis, filariasis, dengue and yellow fever a major source of illness and death worldwide, particularly in tropical and subtropical area [1]. The Culex quinquefasciatus is a major public health problems in India and filariasis is potentially risk of infection [2] These diseases affect the health and quality of life of millions of people in Worldwide [3]. An estimated 120 million people in tropical and subtropical areas of the world are infected with lymphatic filariasis [4]. Moreover, mosquitoes cause allergic responses in humans that include local skin and systemic reactions [5].

Such serious diseases are becoming increasingly difficult because of the high rate of reproduction and development of resistance to insecticides in mosquitoes [6]. The use of chemical control of mosquitoes is remaining as a main part of integrated vector management [7-8]. According to Word Health Organization pesticide, the major insecticides used against mosquitoes are pyrethroids and organophosphates [7-8]. Although, factors including the development of resistance to insecticides are leading to morbidity and mortality due to malaria and other vector-borne diseases. Insect resistance has been reported to chemical class of insecticide used in vector control programs and insect growth regulators [9].

The search for alternative pesticides and control measures that pose no risk or posing minimal risk to human health and the environment is of great interest from the preventive medicine point of view [10]. Pyrethrin-based mosquito liquid formulations are widely used in many countries, especially in the house hold of rural population. Interest in botanical pesticides revived during recent years, because of the deleterious effects of synthetic insecticides, including lack of selectivity, impact on the environment and the emergence and spread of pest resistance. The naturally occurring pesticides appear to have a promising role in the development of future commercial pesticides for safety of the environment and public health [11-12]. Essential oils from plant species, celery (Apiumgraveolens), caraway (Carum carvi), zedoary (Curcuma zedoaria), long pepper (Piper longum) and Chinese star anise (Illicium verum), were studied adulticidal activity against mosquito vectors [13]. Adulticidal activity of five essential oils such as Citrus sinensis, Mentha pipreta, Carvocryl oil, Citronela oil and citral oil against Cx. Quinquefasciatu [14]. The fumigant toxicity of essential oils from 15 species of African plants against Anopheles gambiae in the laboratory conditions [15].

Plant essential oils are volatile substances found in a various plants. This oil isolated from plant sourse, but thus oils are consisting of mixtures of many compounds. Botanical based oils were the first preservatives used by man, their natural state within plant tissues and as oils obtained by water distillation. The oils composed by isoprenoid compounds, mainly mono-and sesquiterpenes are the carriers of the smell found in aromatic plants [16]. The uses of commercial, essential oils are used in four primary ways: pharmaceuticals, flavor enhancers in many food products, odorants in fragrances and insecticides.

At present, evaluation of essential oils against mosquitoes and isolation, identification and development of natural products from them are under the focus of numerous research programmes around the globe. There is a renewed interest in plant essential oils products as sources of new insect controlling agents, because they may be biodegradable to nontoxic compounds, thus minimizing the accumulation of harmful residues, leading them to be more environmentally friendly compared to synthetic compounds [17]. 
The present study was undertaken to evaluate the bio-efficacy of some essential oils (EOs) against Culex quinquefasciatus adults mosquito and to study effects of the effective oils on adults of the mosquito.

\section{MATERIALS AND METHODS}

\section{Materials}

\section{Botanical essential oils}

For the present study, twenty two botanical essential oils were procured from Tegraj and Co (P) Ltd, India (A commercial producer of plant essential oils and aromatic sources) were used in this study. The essential oils (EOs) were selected primarily on the basis of ethno-botanical information and various biological effects, the following 22 essential oils (EOs) were selected: Aniseed (Pimpinella anisum Linn.), Bergamot (Citrus bergamia Risso.), Calamus (Acorus calamus L.), Camphor (Cinnamomum camphora Linn.), Cedarwood (Cedrus atlantica Endl), Cinnamon (Cinnamomum veerum J. S. Presl), Citronella (Cymbopogon nardus Linn.), Clove (Myrtus caryophyllus Linn.), Eucalyptus (Eucalyptus globulus Labill.), Geranium (Pelargonium graveollens L.), Lemon (Citrus limon Linn.), Lemongrass (Cymbopogon flexuosus J. F. Watson), Lime (Citrus aurantifolia Christm.), Luchi (Gaultheria fragrantissima Cham), Nutmeg (Myritica fragrans Houtt.), Orange (Citrus sinensis Linn.), Palmarosa (Cymbopogon martin Stapf), Pine (Pinus radiate D. Don), Rose mary (Rosmarinus officinalis Linn.), Thyme (Thymus vulgaris Linn.), Tulsi (Ocimum sanctum Linn.) and Vetiver (Vetiveria zizanioides Linn.). The essential oils were stored in the refrigerator until used for bioassay experiments.

\section{Maintenance of test organism}

The study organism of $C x$. quinquefasciatus, was maintained in several generations at Entomology Research Institute, Loyola College, Chennai, Tamil Nadu, India. Mosquitoes were free of exposure to pathogens and insecticides and maintained at $26 \pm 1{ }^{\circ} \mathrm{C}$ and $60-80 \%$ relative humidity (RH). Larvae were fed on dog biscuits and yeast powder in a ratio 3:2 until moulting to become pupae, pupae was transferred into a mosquito rearing cage. The pupae were transferred from culture trays to glass beakers containing tap water and placed in cages (45 x45 x $45 \mathrm{~cm})$, where adults emerged. The cages was made up of metal and covered with a muslin cloth. The emergent adults were fed with $10 \%$ glucose solution dipped in cotton.

\section{Methods}

\section{Knock-down and adulticidal activity}

The Knock-down and killing bioassay was performed according to WHO protocol [18]. The selected essential oil was prepared in $2 \mathrm{ml}$ of acetone. A single dose of the oil (10\%) was used in the preliminary screening. Each essential oil were prepared in $2 \mathrm{ml}$ of acetone and applied on Whitman no. 1 filter papers (size $12 \times 15 \mathrm{~cm}^{2}$ ), control papers were treated with $2 \mathrm{ml}$ of acetone alone and placed in exposure tubes. 3-5 $\mathrm{d}$ old sugar fed mosquitoes (In each tube, 20 adult mosquitoes) were exposed on treated paper for one hour and knocked down and live mosquitoes were recorded at every 5 minute intervals. After onehour exposure mosquitoes was transferred into recovery test tubes for 24 hour mortality observation. Five replicates were run at a time with control. The reference insecticide was used with $0.05 \%$ deltamethrin impregnated paper as a comparison. The median knock-down time (KT $\mathrm{KT}_{50}$ and $\left.\mathrm{KT}_{90}\right)$ and knock-down dose $\left(\mathrm{KD}_{50}\right.$ and KD 90 ) were calculated by Probit analysis.

$$
\text { Adult Knock down }(\%)=\frac{\text { Number of adults }}{\text { Number of adults released }} \times 100
$$

\section{Data analysis}

Statistical analysis was performed using SPSS software package, version 15. The values were analyzed by one way analysis of variance (ANOVA) followed by Duncan's multiple range test (DMRT)[19]. The median Knock down time $\left(\mathrm{KT}_{50}\right.$ and $\left.\mathrm{KT}_{90}\right)$ and lethal dose $\left(\mathrm{KD}_{50}\right.$ and $\left.\mathrm{KD}_{90}\right)$ was carried out by Profit analysis [20]. $p$ value of $<0.05$ was considered to represent Significant differences. The corrected percent mortality was evaluated by using Abbott's formula [21].

$$
\text { Corrected mortality }(\%)=\frac{\text { Mortality in control }(\%)-\text { Mortality in treatment }(\%)}{100-\text { Mortality in control }(\%)} \times 100
$$

\section{RESULTS}

\section{Percentage of knock-down and killing effect}

The screening efficacy of Knock-down and killing effect of the plant oil on Culex quinquefasciatus was studied and is illustrated in the table 1 . In the present preliminary screening study a single dose $(10 \%)$ of EOs was used and acetone served as control and reference insecticide ( $0.05 \%$ deltamethrin) was also used as comparison.

Table 1: Preliminary screening (mean \pm SE, No. of five replicates) of essential oils (EOs) for knock-down and killing effect at $10 \% / \mathrm{cm}^{2}$ by

\begin{tabular}{|c|c|c|}
\hline Plant essential oils & \% knock-down $\left(\mathrm{cm}^{2}\right)$ at $1 \mathrm{~h}$ & Mortality (\%) after $24 \mathrm{~h}$ \\
\hline Aniseed & $73.0 \pm 0.61^{f}$ & $54.3 \pm 1.23^{\mathrm{f}}$ \\
\hline Bergamot & $60.0 \pm 0.52^{\text {cde }}$ & $36.3 \pm 1.21^{\mathrm{bc}}$ \\
\hline Calamus & $100 \pm 0.00^{\mathrm{h}}$ & $100 \pm 0.00^{\mathrm{i}}$ \\
\hline Camphor & $100 \pm 0.00^{\mathrm{h}}$ & $100 \pm 0.00^{\mathrm{i}}$ \\
\hline Cedarwood & $63.3 \pm 0.31^{\mathrm{def}}$ & $39.0 \pm 0.51^{\mathrm{de}}$ \\
\hline Cinnamon & $100 \pm 0.00^{\mathrm{h}}$ & $96.6 \pm 0.82^{\mathrm{i}}$ \\
\hline Citronella & $100 \pm 0.00^{\mathrm{h}}$ & $100 \pm 0.00^{\mathrm{i}}$ \\
\hline Clove & $100 \pm 0.00^{\mathrm{h}}$ & $100 \pm 0.00 \mathrm{i}$ \\
\hline Eucalyptus & $100 \pm 0.00^{\mathrm{h}}$ & $100 \pm 0.00^{\mathrm{i}}$ \\
\hline Geranium & $86.6 \pm 0.31 \mathrm{~g}$ & $58.3 \pm 0.82^{\mathrm{f}}$ \\
\hline Lemon & $36.6 \pm 0.32^{b}$ & $16.6 \pm 0.34^{b}$ \\
\hline Lemongrass & $100 \pm 0.00^{\mathrm{h}}$ & $91.3 \pm 2.34^{\mathrm{h}}$ \\
\hline Lime & $66.6 \pm 0.32^{\text {ef }}$ & $38.6 \pm 0.81^{\mathrm{de}}$ \\
\hline Luchi & $62.0 \pm 0.31 \mathrm{~d}^{\mathrm{ef}}$ & $38.0 \pm 0.52^{\mathrm{de}}$ \\
\hline Nutmeg & $53.0 \pm 0.32^{\mathrm{cd}}$ & $27.3 \pm 1.22^{b}$ \\
\hline Orange & $53.3 \pm 0.34^{\mathrm{cd}}$ & $35.3 \pm 0.31^{\mathrm{cd}}$ \\
\hline Palmarosa & $50.0 \pm 1.00^{c}$ & $36.6 \pm 0.82^{\mathrm{cd}}$ \\
\hline Pine & $100 \pm 0.00^{\mathrm{h}}$ & $100 \pm 0.00^{\mathrm{i}}$ \\
\hline Rose mary & $73.3 \pm 0.32^{\mathrm{f}}$ & $62.0 \pm 0.53 \mathrm{~g}$ \\
\hline Thyme & $100 \pm 0.00^{\mathrm{h}}$ & $97.6 \pm 0.81^{\mathrm{i}}$ \\
\hline Tulsi & $100 \pm 0.00^{\mathrm{h}}$ & $96.6 \pm 0.82^{\mathrm{i}}$ \\
\hline Vetiver & $60.0 \pm 0.51^{\text {cde }}$ & $38.6 \pm 1.33^{\mathrm{de}}$ \\
\hline Deltamethrin $(0.05 \%)$ & $100 \pm 0.00^{\mathrm{h}}$ & $100 \pm 0.00^{\mathrm{i}}$ \\
\hline Solvent (Acetone) & $0.0 \pm 0.00^{\mathrm{a}}$ & $3.12 \pm 1.24^{\mathrm{a}}$ \\
\hline
\end{tabular}
impregnated paper method against adult Culex quinquefasciatus mosquito

Values with the same letter were not significantly different $(P<0.05)$ by one way ANOVA with DMRT. 
The results clearly indicated that $100 \%$ knock-down and adult mortality was recorded at $10 \%$ dose of calamus, camphor, cinnamon, citronella, clove, eucalyptus, lemongrass, pine, thyme and tulsi oils respectively. The lowest knock-down and adulticidal activity of $36.6 \%$ and $15.4 \%$ were recorded in lemon oil. Reference insecticide $(0.05 \%$ detramethrin) showed $100 \%$ knock-down and adult mortality against $C x$. quinquefasciatus.

\section{Median knock-down time $\left(\mathrm{KT}_{50}\right)$ and $\mathrm{KT}_{90}$}

The $\mathrm{KT}_{50}$ and $\mathrm{KT}_{90}$ of effective essential oils are shown in table 2. At $10 \%$ concentration, clove oil $\left(\mathrm{KT}_{50}=1.8\right.$ and $\mathrm{KT}_{90}=2.03 \mathrm{~min}$ ) was found to be the most potential treatment. It recorded $1.8 \mathrm{~min}$ as $\mathrm{KT}_{50}$ after $1 \mathrm{~h}$ exposure period for citronella $\left(\mathrm{KT}_{50}=2.5\right.$ and $\mathrm{KT}_{90}=28.0$ $\mathrm{min}$ ) and eucalyptus (KT $\mathrm{KT}_{50}=3.6$ and $\mathrm{KT}_{90}=44.3 \mathrm{~min}$ ) oils were also recorded as potentially effective adulticides against $C X$. quinquefasciatus. In $0.05 \%$ detamethrin $\left(\mathrm{KT}_{50}=2.3\right.$ and $\mathrm{KT}_{90}=27.13$ min) was registered after 1 hour exposure treatment period.

\section{Median knock-down dose (KD 50$)$ and KD 90}

Ten essential oils were identified as potential treatments in screening bioassay of knock-down and killing activity. Tables 3a and $3 \mathrm{~b}$ present the median knock-down dose $\left(\mathrm{KD}_{50}\right.$ and $\left.\mathrm{KD}_{90}\right)$ of the essential oils against $C x$. quinquefasciatus adults at $10 \%$ concentration.

After $15 \mathrm{~min}$ exposure period clove oil registered the lowest knock-down dose which was calculated as $\left(\mathrm{KD}_{50}=1.8 \% / \mathrm{cm}^{2}\right.$ and $\left.\mathrm{KD}{ }_{90}=11.2 \% / \mathrm{cm}^{2}\right)$. Next to clove oil citronella $\left(\mathrm{KD}_{50}=3.0 \%\right.$ and $\left.\mathrm{KD} 90=11.5 \% / \mathrm{cm}^{2}\right)$ and eucalyptus $\left(\mathrm{KD}_{50}=3.4\right.$ and $\mathrm{KD}_{90}=$ $11.6 \% / \mathrm{cm}^{2}$ ) oils were also effective since they recorded lower median knock-down dose.

Tulsi $\left(\mathrm{KD}_{50}=7.4\right.$ and $\left.\mathrm{KD} \mathrm{p}_{90}=16.4 \% / \mathrm{cm}^{2}\right)$ and calamus $\left(\mathrm{KD}_{50}=8.7\right.$ and $\mathrm{KD}_{90}=22.4 \% / \mathrm{cm}^{2}$ ) oils were the least effective knock-down treatment. The lower and upper $95 \%$ confidence limits for clove oil were calculated as 0.2 and 4.2 min respectively.

Table 2: Median knock-down time $\left(\mathrm{KT}_{50}\right)$ and $\mathrm{KT}_{90}$ of effective essential oils against Culex quinquefasciatus at $10 \% / \mathrm{cm}^{2}$ after $1 \mathrm{hour}$ exposure period

\begin{tabular}{|c|c|c|c|c|c|c|c|}
\hline \multirow[t]{2}{*}{ Plant ssential oils } & \multirow[t]{2}{*}{$\mathrm{KT}_{50}$ (min) } & \multicolumn{2}{|c|}{$95 \% C^{b}$} & \multirow{2}{*}{$\begin{array}{l}\mathrm{KT}_{90} \\
\text { (min) }\end{array}$} & \multicolumn{2}{|c|}{$95 \% C^{b}$} & \multirow[t]{2}{*}{ Chi-square } \\
\hline & & LCL & UCL & & LCL & UCL & \\
\hline Calamus & 22.4 & 19.35 & 34.17 & 48.1 & 35.98 & 124.4 & 6.1 \\
\hline Camphor & 11.0 & 8.324 & 54.58 & 32.7 & 27.35 & 58.23 & 7.2 \\
\hline Cinnamon & 7.6 & 4.322 & 24.45 & 47.6 & 36.56 & 65.56 & 11.8 \\
\hline Citronella & 2.5 & 1.123 & 5.842 & 28.0 & 15.34 & 36.54 & 9.6 \\
\hline Clove & 1.8 & 0.214 & 4.231 & 2.03 & 12.33 & 30.12 & 8.1 \\
\hline Eucalyptus & 3.6 & 1.243 & 15.44 & 44.3 & 28.45 & 67.84 & 9.6 \\
\hline Lemongrass & 20.3 & 16.36 & 23.50 & 44.6 & 40.86 & 49.86 & 3.5 \\
\hline Pine & 15.4 & 12.44 & 26.34 & 26.3 & 43.07 & 32.10 & 4.2 \\
\hline Thyme & 19.7 & 15.67 & 27.56 & 43.6 & 35.56 & 78.54 & 3.1 \\
\hline Tulsi & 24.4 & 13.24 & 25.23 & 52.3 & 35.43 & 67.54 & 4.2 \\
\hline Deltamethrin $(0.05 \%)$ & 12.0 & 9.310 & 64.59 & 42.6 & 37.37 & 68.24 & 7.5 \\
\hline
\end{tabular}

Chi-square value significant at $\mathrm{P}<0.05$ level, ${ }^{\mathrm{b} C L}$ : confidence limits; LCL: lower confidence limits; UCL: upper confidence limits, $\mathrm{KT}_{50}=\mathrm{Knock}_{\mathrm{K}}$ down time required to kill $50 \%$ of the population exposed, $\mathrm{KT}_{90}=$ Knock down time required to kill $90 \%$ of the population exposed

Table 3a: Median knock-down dose $\left(\mathrm{KD}_{50}\right)$ and $\mathrm{KD}_{90}$ of effective essential oils against female adult $\mathrm{Cx}$. quinquefasciatus at $10 \% / \mathrm{cm}^{2}$ after 1 $\mathrm{h}$ exposure period

\begin{tabular}{|c|c|c|c|c|c|c|c|c|}
\hline \multirow[t]{2}{*}{ Plant ssential oils } & \multirow{2}{*}{$\begin{array}{l}\text { Exposure } \\
\text { period (min) }\end{array}$} & \multirow[t]{2}{*}{$\mathrm{KD}_{50}(\%)$} & \multicolumn{2}{|c|}{$95 \% C^{b}$} & \multirow[t]{2}{*}{ KD $90(\%)$} & \multicolumn{2}{|c|}{$95 \% C L^{b}$} & \multirow[t]{2}{*}{ Chi-square } \\
\hline & & & LCL & UCL & & LCL & UCL & \\
\hline \multirow[t]{4}{*}{ Calamus } & 15 & 8.7 & $*$ & * & 22.4 & * & * & 5.8 \\
\hline & 30 & 5.0 & 3.79 & 9.15 & 17.1 & 12.1 & 40.1 & 3.5 \\
\hline & 45 & 1.9 & 0.87 & 2.75 & 12.4 & 9.08 & 21.9 & 2.4 \\
\hline & 60 & 0.3 & -2.25 & 0.59 & 6.1 & 4.80 & 9.13 & 2.5 \\
\hline \multirow[t]{4}{*}{ Camphor } & 15 & 1.8 & -10.8 & 4.16 & 18. & 10.4 & 337.9 & 1.5 \\
\hline & 30 & 1.0 & 0.23 & 11.3 & 16.2 & 18.2 & 428.2 & 1.7 \\
\hline & 45 & -1.8 & -6.58 & 0.60 & 9.6 & 6.61 & 22.7 & 2.6 \\
\hline & 60 & -2.4 & -8.20 & -0.67 & 5.7 & 4.22 & 10.3 & 2.7 \\
\hline \multirow[t]{4}{*}{ Cinnamon } & 15 & 4.6 & $*$ & $*$ & 11.4 & $*$ & $*$ & 4.4 \\
\hline & 30 & 2.8 & * & $*$ & 10.1 & $*$ & $*$ & 12.5 \\
\hline & 45 & 0.2 & $*$ & $*$ & 6.0 & $*$ & $*$ & 8.5 \\
\hline & 60 & -1.8 & -5.39 & -0.48 & 4.6 & 3.61 & 7.21 & 0.8 \\
\hline \multirow[t]{4}{*}{ Citronella } & 15 & 3.0 & 2.22 & 4.34 & 11.5 & 8.44 & 20.7 & 0.8 \\
\hline & 30 & 0.8 & -0.90 & 1.66 & 8.9 & 6.64 & 15.3 & 0.6 \\
\hline & 45 & -0.4 & -2.25 & 0.38 & 5.1 & 4.11 & 7.28 & 0.2 \\
\hline & 60 & -0.6 & -2.07 & 0.00 & 2.5 & 2.06 & 3.31 & 2.9 \\
\hline \multirow[t]{4}{*}{ Clove } & 15 & 1.8 & 0.54 & 2.82 & 11.2 & 7.99 & 22.1 & 0.01 \\
\hline & 30 & -0.2 & -2.02 & 0.58 & 5.7 & 4.54 & 8.28 & 0.1 \\
\hline & 45 & -0.5 & -1.83 & 0.06 & 2.3 & 1.89 & 3.02 & 1.7 \\
\hline & 60 & -0.8 & -2.82 & -0.46 & 1.4 & 1.14 & 2.02 & 0.1 \\
\hline
\end{tabular}

Chi-square value significant at $\mathrm{P}<0.05$ level, ${ }^{\mathrm{b}} \mathrm{CL}$ : confidence limits LCL: lower confidence limits UCL: upper confidence limits, KD $50=\mathrm{Knock}_{\text {-down }}$ dose required to kill $50 \%$ of the population exposed, KD $90=$ Knock-down dose required to kill $90 \%$ of the population exposed, $*=$ Knock-down dose could not be determined. 
Table 3b: The $\mathrm{KD}_{50}$ and $\mathrm{KD}_{90}$ of effective essential oils against female adult $C_{x}$. quinquefasciatus

\begin{tabular}{|c|c|c|c|c|c|c|c|c|}
\hline \multirow[t]{2}{*}{ Plant ssential oils } & \multirow{2}{*}{$\begin{array}{l}\text { Exposure period } \\
\text { (min) }\end{array}$} & \multirow[t]{2}{*}{$K_{50}(\%)$} & \multicolumn{2}{|c|}{$95 \% C^{b}$} & \multirow[t]{2}{*}{ KD90 (\%) } & \multicolumn{2}{|c|}{$95 \% C^{b}$} & \multirow[t]{2}{*}{ Chi-square } \\
\hline & & & LCL & UCL & & LCL & UCL & \\
\hline \multirow[t]{4}{*}{ Eucalyptus } & 15 & 3.4 & $*$ & $*$ & 11.6 & $*$ & $*$ & 4.1 \\
\hline & 30 & 1.9 & 0.80 & 2.76 & 10.3 & 7.61 & 18.4 & 0.6 \\
\hline & 45 & 0.3 & -1.54 & 0.83 & 6.1 & 4.88 & 8.92 & 2.2 \\
\hline & 60 & 0.2 & $*$ & $*$ & 2.7 & $*$ & $*$ & 4.0 \\
\hline \multirow[t]{4}{*}{ Lemongrass } & 15 & 5.3 & $*$ & $*$ & 11.2 & $*$ & $*$ & 4.9 \\
\hline & 30 & 4.2 & * & $*$ & 2.2 & $*$ & $*$ & 6.6 \\
\hline & 45 & 1.9 & $*$ & $*$ & 7.3 & $*$ & $*$ & 4.0 \\
\hline & 60 & 0.7 & -9.79 & 2.00 & 3.9 & 2.57 & 25.3 & 5.1 \\
\hline \multirow[t]{4}{*}{ Pine } & 15 & 5.7 & 4.49 & 6.71 & 13.8 & 10.0 & 24.6 & 2.1 \\
\hline & 30 & 4.3 & $*$ & 9.07 & 16.2 & $*$ & * & 5.5 \\
\hline & 45 & 1.2 & -2.39 & -2.53 & 14.0 & 8.95 & 47.3 & 1.3 \\
\hline & 60 & -1.5 & 0.23 & 4.32 & 6.50 & 8.31 & 19.2 & 4.3 \\
\hline \multirow[t]{4}{*}{ Thyme } & 15 & 7.5 & $*$ & $*$ & 16.5 & $*$ & * & 5.1 \\
\hline & 30 & 4.6 & $*$ & * & 13.0 & $*$ & $*$ & 4.9 \\
\hline & 45 & 1.9 & 0.87 & 2.75 & 10.1 & 7.49 & 17.4 & 2.4 \\
\hline & 60 & 1.2 & 0.56 & 2.54 & 9.8 & 6.81 & 16.5 & 2.1 \\
\hline \multirow[t]{4}{*}{ Tulsi } & 15 & 5.3 & * & $*$ & 14.4 & * & * & 6.3 \\
\hline & 30 & 4.0 & $*$ & $*$ & 12.5 & $*$ & $*$ & 5.2 \\
\hline & 45 & 2.2 & $*$ & $*$ & 12.9 & $*$ & $*$ & 4.3 \\
\hline & 60 & 0.2 & -1.62 & 1.25 & 7.6 & 4.82 & 13.6 & 3.4 \\
\hline \multirow[t]{4}{*}{ Tulsi } & 15 & 7.4 & $*$ & $*$ & 16.4 & $*$ & $*$ & 6.6 \\
\hline & 30 & 4.1 & $*$ & $*$ & 11.5 & $*$ & $*$ & 5.2 \\
\hline & 45 & 2.5 & $*$ & $*$ & 11.9 & $*$ & $*$ & 4.5 \\
\hline & 60 & 0.2 & -1.66 & 1.15 & 7.7 & 5.89 & 12.6 & 3.3 \\
\hline \multirow[t]{4}{*}{ Deltamethrin (0.05\%) } & 15 & 1.2 & -2.39 & -2.53 & 14.0 & 8.95 & 47.3 & 1.4 \\
\hline & 30 & 0.8 & -0.90 & 1.66 & 8.9 & 6.64 & 15.3 & 0.6 \\
\hline & 45 & -0.4 & -2.25 & 0.38 & 5.1 & 4.11 & 7.28 & 0.2 \\
\hline & 60 & -0.6 & -2.07 & 0.00 & 2.6 & 2.06 & 3.32 & 2.8 \\
\hline
\end{tabular}

Chi-square value significant at $\mathrm{P}<0.05$ level, bCL: confidence limits; LCL: lower confidence limits; UCL: upper confidence limits, KD ${ }_{50}=$ Knock-down dose required to kill $50 \%$ of the population exposed, $\mathrm{KD}_{90}=$ Knock-down dose required to kill $90 \%$ of the population exposed, ${ }^{*}=$ Knock-down dose could not be determined

\section{DISCUSSION}

In the present study 22 essential oils registered knock-down and adulticidal effects. Plenty of literature is available with regard to bio efficacy of volatile oils against vector mosquitoes. These findings are comparable to those of Vartak and Sharma [22] have reported the knock-down effect of terpenoids of volatile oils against $A$. aegypti adult females.

Prajapati et al. [23] have studied the essential oils viz., Cinnamomum zeylanicum, Cuminum cyminum, Cyperus scariosus, Curcuma longa, Juniperus macropoda, Ocimum basilicum, Rosmarinus officicinalis, Nigella sativa, Pimpinella anisum, and Zingiber officinale for adulticidalt activity against three mosquito species; Anopheles stephensi, Aedes aegypti and Culex uinquefasciatus. Omoloa et al. [24] have reported the fumigant toxicity of essential oils from 15 species of African plants against Anopheles gambiae in the laboratory. They reported that oils of 6 plant species viz., Tarchonanthus camphoratus, Lippia javanica, Plectranthus marruboides, Tetradenia riparia, Lippia ukambensis and Conyza newii were found to be relatively more toxic, with $C$. newii and $P$. marruboides showing the highest potency.

Rajkumar and Jabanesan [25] reported the knocking down and killing effects of Solanum aerianthum D. Don. leaf extracts against the mosquito Culex quinquefasciatus Say. Jeyabalan et al. [26] have reported the adulticidal effect of Pelargonium citrosa on Anopheles stephensi, with $\mathrm{LC}_{50}$ and $\mathrm{LC}_{90}$ values as $1.56 \%$ and $5.22 \%$ respectively. Nathan et al. [27], who reported the adulticidal activity of methanol extract of Dysoxylum malabaricum leaves against Anopheles stephensi. Adulticidal activity of five essential oils (Citrus sinensis, Mentha pipreta, Carvocryl oil, Citronela oil and citral oil) at different concentrations and time intervals was determined. The Rutaceae oil ( $C$. sinensis) was found as the most toxic against $C x$. Quinquefasciatus [28]. A large number of plants are reported to have adulticidal activity [28, 29-30]. Kovendan et al. [31] found the adulticidal activity of methanol extract of Acalypha alinifolia leaves against three mosquito species, Ae. aegypti, An. stephensi and Culex quinquefasciatus. Dua et al. [30] reported the adulticidal activity of essential oil of Valeriana jatamansi root against An. stephensi, An. culicifacies, Ae. aegypti, Ae. albopictus, and Cx. quinquefasciatus, with $\mathrm{LD}_{50}$ and $\mathrm{LD}_{90}$ values were $0.14,0.16,0.09,0.08,0.17 \mathrm{mg} / \mathrm{cm}^{2}$ and $0.24,0.34,0.25,0.21,0.28 \mathrm{mg} / \mathrm{cm}^{2}$, respectively; Whereas $\mathrm{KDT}_{50}$ and $\mathrm{KDT}_{90}$ values were 13, 13, 12, 13, $18 \mathrm{~min}$ and 24, 25, 21, 20, $42 \mathrm{~min}$ against An. stephensi, An. culicifacies, Ae. aegypti, An. albopictus and Cx. quinquefasciatus, respectively, using $0.28 \mathrm{mg} / \mathrm{cm}^{2}$ impregnated papers.

Yang et al. [32] have studied the adulticidal activity of five essential oils against Culex pipines. They found that the Rutaceae oil obtained from Citrus sinesis was the most effective adulticidal treatment. Other plant species that are reported to possess adulticidal activity includes: Curcuma aromatic against Ae. aegypti [17]. The adulticidal activity of ethanol extract of Apium graveolens seeds against Aedes aegypti has been reported [33]. Dua et al. [29] reported the adulticidal activity of essential oil of leaves of Lantana camara against Ae. aegypti, Cx. quinquefasciatus, An. culicifacies, An. fluvialitis and $A n$. stephensi, $\mathrm{LD}_{50}$ values were $0.06,0.05,0.05,0.05$ and 0.06 $\mathrm{mg} / \mathrm{cm}^{2}$ while $\mathrm{LD}_{90}$ values were $0.10,0.10,0.09,0.09$ and 0.10 $\mathrm{mg} / \mathrm{cm}^{2}$ respectively. Whereas $\mathrm{KDT}_{50}$ values were $20,18,15,12,14$ min and $\mathrm{KDT}_{90}$ values were 35, 28, 25, 18, and 23 min against $A e$. aegypti, Cx. quinquefasciatus, An. culicifacies, An. fluviatilis and An. stephensi, respectively on $0.208 \mathrm{mg} / \mathrm{cm}^{2}$ impregnated paper. The target of many insecticides is the nervous system and in particular, acetylcholine esterase (AChE). However little information is available on mode of adulticidal activity of essential oil. Ware [34] (1994) has reported that the only way volatile insecticides can enter the pest's body is through the respiratory system.

In the present study the volatile oils showed variation in Knockdown and adulticidal activity when tested by impregnated filter paper method. Calamus, camphor, cinnamon, citronella, clove, eucalyptus, lemongrass, pine, thyme and tulsi oils recorded 100 per cent Knock-down and adult mortality at $10 \% / \mathrm{cm}^{2}$ dose only in WHO 
test tube method. Therefore, the observed Knock-down and adulticidal activity of the EOs may be attributed to these compounds.

\section{CONCLUSION}

The obtained results indicate that the essential oil (EOs) has potential to be developed as an eco-friendly insecticide against mosquito. The results of the present study could be useful in promoting research aimed at the development of new insecticidal agents for adult mosquito control with filter paper method. The impregnated paper assay finding may be utilized for the development of botanical based insecticides as alternative to synthetic insecticides for adult mosquito control.

\section{ACKNOWLEDGEMENT}

The senior author profoundly indebted to thank the Rv. Fr, Director, Entomology Research Institute, Loyola College, Chennai and former Vice-Chancellor of Bharathiar University, Coimbatore and University of Madras, for the monetary support and for his constructive suggestions.

\section{CONFLICT OF INTERESTS}

\section{Declared none}

\section{REFERENCES}

1. Jang YS, Ahn YJ, Lee HS. Larvicidal activity of Brazilian plants against Aedes aegypti and Culex pipiencs. (Diptera: Culicidae). Agric Chem Biotechnol 2002;45:131-4.

2. Agrawal VK, Sashindran VK. Lymphatic filariasis in India problems, challenges and new initiatives. Med J Armed Forces India 2006;62:359-62.

3. Githeko AK, Lindsay SW, Confalonieri UE, Patz JA. Climate change and vector-borne diseases: a regional analysis. Bull WHO 2000;78:1136-47.

4. Fox LM. Infectious Diseases Related To Travel. In CDC Health Information for International Travel 2012. Edited by Brunette GW. New York: Oxford University Press; 2011.

5. Peng Z, Yang J, Wang $\mathrm{H}$, Simons FER. Production and characterization of monoclonal antibodies to two new mosquito aedes aegypti salivary proteins. Insect Biochem Mol Biol 1999;29:909-14.

6. Severini C, Romi R, Marinucci M, Raymond M. Mechanisms of insecticides resistance in field population of Culex pipiens from Italy. J Am Mosq Control Assoc 1993;9:164-8.

7. Curtis CF, Lines JD, Lu B, Renze A. Natural and synthetic repellents. In: Appropriate Technology in Vector Control. CF Curtis. Ed. CRC Press: Boca Raton; 1990. p. 75-92.

8. Zaim M, Jambulingam P. Global insecticide use for vector-borne disesae control. World Health Organization Pesticide Evaluation Scheme (WHOPES). In: World Health Organization Pesticide Evaluation Scheme (WHOPES): World Health Organization: Geneva; 2004.

9. Brogdon WG, McAllister JC. Insecticide resistance and vector control. Emerging Infect Dis 1998;4:605-13.

10. WHO. Expert Committee on Vector Biology and Control Sixteenth report. Geneva; 1999. p. EB108/6.

11. Bowers WS, Sener B, Evans H, Bingal F, Erodogan I. Activity of turkish medicinal plants against mosquitoes Aedes aegypti and Anopheles gambiae. Insect Sci Appl 1995;16:339-42.

12. Sukumar K, Perich MJ, Boobar LR. Botanical derivatives in mosquito control: a review. J Am Mosq Control Assoc 1991;7:210-37.

13. Chaiyasitt D, Choochote W, Rattanachanpichai E, Chaithong U, Chaiwong P, Jitpakdi A, Tippawangkosol P, et al. Essential oils as potential adulticides against two populations of Aedes aegypti, the laboratory and natural field strains, in chiang mai rovince, Northern Thailand. Parasitol Res 2006;99:715-21.

14. Yang P, Ma Y, Zheng S. Adulticidal activity of five essential oils against Culex pipiens quinquefasciatus. Pestic Sci Soc Japan 2005;30:6.
15. Franzios G, Mirotson M, Hatziapostolou E, Kral J, Scouras ZG, Mavragani TP. Insecticidal and genotoxic activities of mint essential oils. J Agric Food Chem 1997;45:2690-4.

16. Omolo MO, Okinyo D, Ndiege IO, Lwandeb W, Hassanali A. Fumigant toxicity of the essential oils of some African plants against Anopheles gambiae sensu stricto. Phytomedicine 2005;12:241-6.

17. Choochote W, Chaiyasit D, Kanjanapothi D, Rattanachanpichai E, Jitpakdi A, Tuetun B, et al. Chemical composition and antimosquito potential of rhizome extract and volatile oil derived from Curcuma aromatica against Aedes aegypti (Diptera: Culicidae). J Vector Ecol 2005;30:302-9.

18. World Health Organization. Instructions for determining the susceptibility or resistance of adult mosquitoes to organochlorine, organophosphate and carbamate insecticides: diagnostic test. Vol. WHO/VBC/81.807. Geneva; 1981.

19. Duncan BD. Multiple range test for correlated and heteroscedastic means. Biometrics 1957;13:359-64.

20. Finney DJ. In: Probit Analysis By. DJ Finney. Vol. 60. 3rd ed. edition. 32 E. 57th St. New York: Cambridge University Press; 1971.

21. Abbott WS. A method of computing the effectiveness of an insecticide. 1925. J Am Mos Control Assoc 1987;3:302-3.

22. Vartak PH, Sharma RN. Vapour toxicity and repellence of some essential oils and terpenoids to adults of Aedes aegypti (L.) (Diptera: Culicidae). Indian J Med Res 1993;97:122-7.

23. Prajapati VV, Tripathi AK, Aggarwal KK, Khanuja SPS. Insecticidal, repellent and oviposition-deterrent activity of selected essential oils against Anopheles stephensi, Aedes aegypti and Culex quinquefasciatus. Bioresour Technol 2005;96:1749-57.

24. Omolo MO, Okinyo D, Ndiege IO, Lwandeb W, Hassanali A. Fumigant toxicity of the essential oils of some African plants against Anopheles gambiae sensu stricto. Phytomedicine 2005; 12:241-6.

25. Rajkumar S, Jebanesan A. Oviposition attractancy of Solanum aerianthum leaf extract for Culex quinquefasciatus. J Expt Zool 2002;59:221-4

26. Jeyabalan D, Arul N, Thangamathi P. Studies on effects of Pelargonium citrosa leaf extracts on malarial vector, Anopheles stephensi Liston. Bioresour Technol 2003;89:185.

27. Nathan SS, Kalaivan K, Sehoon K. Effects of dysoxylum malabaricum Bedd. (Meliaceae) extract on the malarial vector anopheles stephensi liston (Diptera: Culicidae). Bioresource Technol 2006;97:2077-83.

28. Yang P, Ma Y, Zheng S. Adulticidal activity of five essential oils against Culex pipiens quinquefasciatus. Pestic Sci Soc Japan 2005;30:6.

29. Dua VK, Pandey AC, Dash AP. Adulticidal activity of essential oil of Lantana camara leaves against mosquitoes. Indian J Med Res 2010;131:434-9.

30. Dua VK, Alam MF, Pandey AC, Rai S, Chopra AK, Kaul VK, et al. Insecticidal activity of Valeriana Jatamansi (Valerianaceae) against mosquitoes. J Am Mos Control Assoc 2008;24:315-8.

31. Kovendan K, Murugan K, Kumar PM, Thiyagarajan P, William SM. Ovicidal, repellent, adulticidal and field evaluations of plant extract against dengue, malaria and filarial vectors. Parasitol Res 2013;112:1205-19.

32. Yang YC, Lee SH, Lee WJ, Choi DH, Ahn YJ. Ovicidal and adulticidal effects of Eugenia caryophyllata bud and leaf oil compounds on Pediculus capitis. J Agric Food Chem 2003;51:4884-8.

33. Choochote W, Tuetun B, Kanjanapothi D, Rattanachanpichai E, Chaithong U, Chaiwong P, et al. Potential of crude seed extract of celery, Apium graveolens L., against the mosquito Aedes aegypti (L.) (Diptera: Culicidae). J Vector Ecol 2004;29:340-6.

34. Ware GW. The pesticide book. 4th Ed. Fresno CA. Thomson Publications; 1994. p. 386.

\section{How to cite this article}

- M Ramar, S Ignacimuthu, P Manonmani, K Murugan. Adulticidal activity of botanical oils by impregnated paper assay against Culex quinquefasciatus say. Int J Pharm Pharm Sci 2017;9(5):156-160. 